DOI:

\title{
LATVIJAS SKOLĒNU VALODAS (GRAMATISKĀS) KOMPETENCES ANALĪZE
}

\section{ANALYSIS OF LATVIAN STUDENTS' LANGUAGE COMPETENCE}

\author{
Margarita Gavrilina \\ Latvijas Universitāte \\ margarita.gavrilina@lu.Iv
}

\author{
Kaspars Špūle \\ Valsts izglītības satura centrs \\ kaspars.spule@visc.gov.lv
}

\begin{abstract}
ANOTĀCIJA
Raksta mērḳis - analītiski vērtēt Latvijas skolēnu, kuri mācās pamatskolā, valodas prasmes. Skolēnu sasniegumi analizēti, izmantojot valsts latviešu un krievu valodas pārbaudes darbu (diagnosticējošā darba 6. klasē un eksāmena darba 9. klasē) rezultātus. Pētījumā secināts, ka mācību valodas prasmes (valodas kompetence) Latvijas skolēniem ir loti vājas. Pusaudžiem ir grūtības raksturot valodu, izmantojot atsevišḳas valodas vienības, viṇi bieži nespēj veikt uzdevumus, kuros risināma kāda valodas problēmas, sniegtās atbildes ir nepareizas, atbilžu pamatojumam izmantoti mazsvarīgi vai nebūtiski argumenti. Lielākā daḷa skolēnu nespēj aizstāvēt savu viedokli, runājot par dažādām valodas lietojuma problēmām. Galvenais iemesls, kāpēc skolēnu sasniegumi valodas kompetences apguvē tik zemi, ir tas, ka dzimtās valodas apguves procesā viṇiem nav izveidojies lingvisktiskais valodas skatījums, nav izpratnes par valodu kā veselumu, sistēmu.
\end{abstract}

Atslēgas vārdi: valodas kompetence, gramatiskās (valodas) spējas, pamatskolas skolēni, pirmā (dzimtā) valoda

Key words: Language competence, grammatical ability, primary school pupils, native language

Pēdējos desmit gados īpaša uzmanība lingvodidaktikā tiek veltīta skolēnu dzimtās (resp., pirmās) valodas mutvārdu un rakstu formas apguves līmeṇa kritumam. Mūsdienās jauniešu runā vērojamas vairākas valodiska rakstura saziņas problēmas - radoša, nevērīga pieeja valodas normu lietojumam un 
visa iznīcināšanas stereotips. Pēc valodnieku domām, tas raksturīgs ne tikai valodas lietojumam pusaudžu vidū, bet visā sabiedrībā. Vasilijs Himiks uzskata, ka 21. gadsimta sākumā „noticis globāls kritums, masu „ekspresivācija" publiskajā saziṇā, oficiālajā komunikācijā, kurā bieži parādās ne tikai ekspresīvā sarunu valoda, bet arī līdz šim nepiel̦aujamā vienkāršruna, aizskaroši, rupji vārdi, vulgārismi" (Химик 2004: 1) Bez šaubām, šāda attieksme pret valodu ietekmē skolēnu valodas kompetences attīstību.

Kā zināms, veiksmīga saziṇa ir atkarīga no saziṇas partneru valodas prasmes līmeņa. Ja skolēnam mācību procesā neveidojas izpratne par valodas uzbūvi un to, kā tā funkcionē, ja netiek apgūtas visu valodas līmeņu normas, proti, ja nav attīstīta valodas kompetence, tad arī saziņa lielākoties nebūs valodiski kvalitatīva. Protams, valodas sistēmas apguve nedrīkst būt pašmērḳis. Skolēni dzimtās valodas likumsakarības apgūst tādēl, lai pilnveidotu savu valodas kompetenci, tas ir, „sasniegtu tādu līmeni, kas dod iespēju noteikt un motivēti izvēlēties vienu no vairākām valodas vienībām fonēmu, morfēmu, grafēmu, vārdu, sintaktisko konstrukciju" (Хруцкая 2013: 273). Tam būtiska nozīme ir ne tikai pirmās (dzimtās) valodas, bet arī otrās un trešās valodas apguvē. Valodas kompetences attīstība lioti atkarīga arī no skolēna individuālajām domāšanas spējām, tās ātruma un dziļuma. Otrs tikpat būtisks priekšnosacījums (lietderība, ja tā var teikt) skolēna valodas kompetences izaugsmei ir tas, kā tā nodrošina „kulturālu individuālo personību, log̣iskās domāšanas izaugsmi, atmiṇu, iztēli, kā arī attīsta mūsdienīgu domāšanu" (Быстрова 2004: 24). Mācìt skolēnam domāt - mūsdienu izglīīibas viens no svarīgākajiem uzdevumiem. Nav šaubu, ka valodas materiāla apguve to vislabāk arī veicina.

Lingvodidaktikā var atrast vairākas un pat atšḳirīgas valodas kompetences definīcijas. Vienā no pētījumiem akcentēta t. s. zināšanu pieeja. Pēc Natālijas Romanovas un Andreja Filịpova domām, valodas kompetence ir „valodas sistēmas, tās fonētisko vienību un likumu, vārda sastāva, gramatisko formu un modeḷu, funkcionālo stilu un stilistisko līdzekḷu pārzināšana" (Романова, Филиппов 2009: 278). Zinātnieku darbos tiek uzsvērta skolēnu valodas kompetences nozīme vinu komunikatīvās prasmes attīstībā, turklāt norādīts, ka valodas kompetence ietilpst komunikatīvās kompetences struktūrā. Jans van Eks atzīst, ka valodas kompetence - viens no svarīgākajiem komponentiem jebkurā komunikatīvās kompetences izpratnes līmenī - ir prasme izveidot un interpretēt gramatiski pareizus izteikumus (pareizi konstruēt gramatiskās formas un izveidot konkrētās valodas normām atbilstošas sintaktiskās konstrukcijas) (Van Ek 1986: 27). Jel̦ena Bistrova piedāvā šādu valodas kompetences definīciju: „Valodas kompetence - skolēnu prasme izmantot vārdus, to formas, sintaktiskās konstrukcijas atbilstoši literārās valodas normām, izmantot sinonīmijas līdzekḷus, 
visbeidzot - valodas bagātību izmantojums kā priekšnosacījums veiksmīgai valodas lietošanai." (Быстрова 2004: 36)

Pētījumā tika analizēti valsts pārbaudes darbi skolēnu mācību valodā (diagnosticējošais darbs 6. klasē un eksāmena darbs 9. klasē latviešu un krievu valodā) (VPD 2013-2016), kurus veidoja Valsts izglītības satura centrs, sadarbojoties ar dzimtās (latviešu un krievu) valodas skolotājiem. Diagnosticējošo darbu mērḳis ir palīdzēt skolotājiem vērtēt skolēnu sasniegumus un noteikt komunikatīvās, valodas un sociokultūras kompetences apguves problēmas dzimtajā valodā un konstatēt, kādas korekcijas nepieciešamas pedagogiskajā darbībā. Analizējot pārbaudes darbu (2013-2016) rezultātus, galvenā uzmanība tika pievērsta sestās un devītās klases skolēnu spējai izpildīt dažāda veida valodas kompetences pārbaudes uzdevumus un prasmei argumentēt valodas līdzekḷu izmantošanu, kā arī pieḷautajām pareizrakstības kḷūdām.

Rezultātu analīze liecina, ka skolēniem vislielākās problēmas sagādā tieši valodas kompetences pārbaudes uzdevumi. Diagnosticējošajos darbos iekḷautos valodas sistēmas izpratnes (gramatikas) uzdevumus 2013./2014. mācību gadā pareizi izpildījuši 64\% latviešu mācību valodas apguvēji un 52\% krievu mācībvalodas apguvēji, 2014./2015. mācību gadā - attiecīgi 56\% un 44\%, savukārt 2015./2016. gadā - 56\% un 58\% skolēnu.

Trīs gadu šḳērsgriezumā manāms, ka vidējie rezultāti par valodas lietojumu skolēniem ir būtiski mainījušies. Katru gadu šajos darbos netiek pārbaudīta viena un tā pati likumsakarība, līdz ar to iespējama sasniegumu līmen,a maiṇa. Mainot pārbaudāmās prasības, vieglāk secināt, kuras gramatikas likumsakarības nav pietiekami apgūtas un kuras skolēniem sagādā grūtības. Vienā pārbaudes darbā nav iepējams novērtēt visas gramatikas zināšanas. Jāmin, ka krievvalodīgajiem skolēniem gramatikas pārbaudes uzdevumos viszemākie rezultāti ir ne tikai krievu valodā, bet arī latviešu (valsts) valodas pārbaudes darbos. 2013./2014. mācību gadā latviešu valodas pārbaudes darbos valodas sistēmas izpratnes daḷu pareizi bija izpildījuši 63\% sestās klases un 47 \% devītās klases skolēnu.

Valodas kompetences līmenis parādās skolēnu izteikumos, valodas uzdevumu izpildē, kḷūdās, kuras piel̦autas tekstveides uzdevumos. Irina Golovanova norāda, ka valodas kḷūdas kā atkāpes no tradicionālajām normām „var uzskatīt par paradigmālu parādību, kas atspoguḷo individuālo valodas apziņu” (Голованова 2004). Piemēram, sestās klases skolēni dažādas valodas vienības raksturo šādi:

- vārds ir tas, „ko mēs sakām”,

- vārdu savienojums - tas, "piemēram, īpašības vārds un lietvārds”,

- morfēma - tas, „piemēram, priedēklis, sakne, piedēklis, galotne”, „vārda dalıa”, „tas, no kā sastāv vārds”,

- teikums - „tas, kas sastāv no dažiem vārdiem”. 
Skolēnu atbilžu rezultāti pierāda, ka, raksturojot kādu valodas vienību, tikai nelielai daḷai pusaudžu ir priekšstats par būtiskajām vai visām kādai valodas vienībai raksturīgajām pazīmēm.

Sestās klases diagnosticējošo darbu rezultāti apliecina, ka skolēniem nopietnas grūtības sagādā šādi uzdevumi:

- vārdkopu atrašana teikumā atbilstoši dažādiem (morfoloǵiskajiem vai sintaktiskajiem) nosacījumiem,

- valodas zīmju (piemēram, vārda kā vārdšksiras, teikuma) būtisko pazìmju noteikšana,

- vārda sastāva noteikšana un vārddarināšanas ḳēdes veidošana,

- teikuma gramatiskā centra, vienlīdzīgo teikuma locekḷu atrašana.

Skolēnu pieḷauto kḷūdu analīze liecina, ka viṇi vēl pietiekami labi nepārzina gramatiku vai lieto zināšanas neapzināti, neprot sasaistīt uzdevumu izpildē nepieciešamās teorētiskās atziṇas ar reāliem piemēriem no teksta (parasti tāpēc, ka nepareizi izlasa vai nesaprot gramatisko informāciju, kas iekḷauta uzdevumā).

Analizējot devītās klases skolēnu eksāmena darbus, tika secināts, ka visgrūtāk veicies uzdevumos, kuros vajadzēja

- noteikt vārda piederību vārdšksirai,

- izskaidrot pieturzīmju lietojumu un tās iederīgi lietot,

- atrast tekstā konkrētu vārdšķiru vai sintakstisko konstrukciju atbilstoši norādītajām gramatiskajām pazīmēm,

- veidot teikumu atbilstoši uzdevumu nosacījumiem (vārdformu un sintakstisko konstrukciju izmantošana),

- ierakstīt teikumos nepieciešamās pieturzīmes,

- noteikt teksta stilu un žanru.

Zināms, ka spilgts valodas kompetences veidošanas līmeņa rādītājs ir skolēna spēja argumentēt savu viedokli, pildot dažādus gramatikas uzdevumus (morfologijias, ortogrāfijas, sintakses, interpunkcijas u. c.). Mūsu secinājumi liecina, ka tieši gramatiskā argumentācija ir nopietna problēma pamatskolas skolēnu valodas lietojumā. Kā zināms, gramatiskā argumentācija ir teorētiskās argumentācijas veids. No vienas puses, viss ir vienkārši: zini likumu vai valodas normu, saskati risināmo problēmu, formulē secinājumu. No otras puses, skolēnam tas nav vienkārši, jo no viņa tiek gaidītas dziḷas, objektīvas zināšanas un valodas funkcionālās sistēmas izpratne, kā arī valodiskā domāšana. Tieši tāpēc prasme argumentēti veikt valodas uzdevumus ir skolēna vispārīgas izpratnes par valodas sistēmu rādītājs. Skolēnu gramatisko argumentu analīze ḷauj secināt, ka visbiežāk, veicot gramatikas uzdevumus, skolēni izmanto nepareizus vai liekus argumentus.

Piemēram, devītās klases skolēni, pierādot, vai dotie krievu valodas vārdi (распускающиеся (листья) и причудливые (узоры)) ir vai nav vienas 
vārdšķiriras vārdi, pamato savu atbildi šādi: „Šie vārdi ir vienas vārdšḳiras vārdi, jo tie abi

- atbild uz vienu un to pašu jautājumu,

- ir vienādi lokāmi,

- lietoti daudzskaitlī,

- ir atkarīgi no lietvārda,

- nosauc priekšmeta pazīmes."

Neviens arguments nav pareizs. Šajā gadījumā pareizie argumenti būtu šādi: tie ir dažādu vārdšksiru vārdi (darbības vārda divdabja forma un īpašìbas vārds), jo tie

- darināti no dažādu vārdšksiru vārdiem (распускающиеся no darbības vārda, причудливые - no lietvārda),

- atšķirīgi raksturo priekšmetu (распускающиеся - izsaka priekmeta darbības pazīmi; причудливые - norāda uz priekšmeta pastāvīgu pazìmi).

Par valodas kompetenci liecina arī prasme precīzi ievērot ortogrāfijas un interpunkcijas normas, kuru pamatā gan latviešu, gan krievu valodā ir gramatika. Sestās klases skolēniem pārbaudes darbā jāraksta domraksts 150 vārdu apjomā. Rezultāti liecina, ka visbiežāk 6. klases skolēni saņēmuši 0 punktu, tas nozīmē, ka skolēni tekstā piel̦āvuši sešas un vairāk ortogrāfijas kḷūdu. Latviešu valodā arī par interpunkcijas normu ievērošanu visbiežāk ir 0 punktu, piel̦autas astoņas un vairāk kḷūdu. Krievu valodā skolēni ir piel̦āvuši mazāk interpunkcijas kḷūdu nekā latviešu skolēni. Tas, iespējams, tāpēc, ka interpunkcijas normas krievu un latviešu valodā ir līdzīgas un vienu to pašu normu krievu skolēns apgūst divreiz - krievu un vēl latviešu valodas stundās.

9. klases skolēniem eksāmenā jāraksta pārspriedums 250-300 vārdu apjomā. Tāpat kā 6. klases skolēni, arī devītās klases audzēkṇi par temata atbilstību un plānojumu san,em gandrīz maksimālos punktus ar atsevišksiem izṇēmumiem, taču piel̦auj piecas un vairāk ortogrāfijas un sešas un vairāk interpunkcijas kḷūdu, tādēḷ vidēji iegūstot 40\% par ortogrāfijas un tikai 25\% par interpunkcijas normu ievērošanu. Vērtējot skolēnu rakstītos tekstus, vērā tiek n,emts nosacījums, ka par kḷūdu var uzskatìt tikai tās nepareizi lietotās ortogrāfijas un interpunkcijas normas, kuras apgūtas mācību procesā.

N̦emot vērā valodas kompetences kritērijus un to konkrētos rādītājus, kurus formulējusi Jel̦ena Božoviča (Божович 2013: 47-48), tika konstatēts, ka, veicot dažāda veida valodas uzdevumus un izmantojot valodas lïdzekl̦us, skolēni:

- vāji pārzina valodas materiālu, kad nepieciešams nosaukt vai raksturot kādu valodas zīmi, vienību, izmantojot konkrētas pazīmes, vai neprot saskatīt likumsakarības starp valodas zīmēm, 
- veicot valodas uzdevumus, izmanto valodas vienības, bet visbiežāk lieto vispārīgus analīzes pan̄ēmienus, nedemonstrējot prognozējošas darbības,

- veicot kādu uzdevumu, tai skaitā arī problemātisku, nereti izmanto nepareizus, neesošus vai liekus argumentus,

- bieži vien nav gatavi aizstāvēt savu uzdevumu izpildes variantu, nav emocionāli refleksīvas attieksmes (emocionālais (gribas) komponents) pret savu veikumu vai viedokli.

Kādi ir šādas situācijas iemesli? Iespējams, vairāki. Šajā rakstā nerunāsim par tādiem iemesliem kā vērtīborientētām problēmām (vai pusaudžu vidū gramatiski pareiza valoda ir vērtība?), mūsdienu pusaudžu valodas variācijām, to psihologiskajiem pamatiem. Šie iemesli vēl ir zinātniski jāpēta. Rakstā vairāk uzmanības pievērsīsim tiem iemesliem, kas visnotaḷ izriet no skolēnu valodas kompetences problēmām.

Viens no tiem - grūtības valodas sistēmas izpratnē, ar kurām saskaras mūsdienu skolēni. Acīm redzama problēma ir tas, ka skolēniem valodas kompetences apguve nepavisam nav viegls process. Grūtības sagādā, pirmkārt, tas, ka runas darbības, kuras viniiem jāveic, ir kaut kāda abstrakcija (bieži - abstrakciju abstrakcija). Lai to īstenotu, nepieciešama logíiskā domāšana. J. Božoviča atgādina, ka „nevar ignorēt to, cik sarežğîti cilvēkam saprast jebkuru zìmju sistēmu un cik ierobežotas ir iespējas un laiks to apgūt - varbūt pat viens no iespaidīgākajiem faktoriem, lai skolēns to varētu saprast" (Божович 1997: 35). Otrkārt, tas, ka bērnu valodas kompetences attīstības dinamika "saistīta ar bērnu regresijas brǐžiem un krīzēm” (Божович 2013: 47), bet viena no krīzēm notiek tieši pamatskolā. Treškārt, skolēna valodas kompetences saturs ir pietiekami sarežğìts, jo tā ietver skolēnu runas pieredzi, viņa zināšanas par valodu un valodas izjūtu. Valodas pieredze mūsdienu jauniešiem dzimtajā valodā un priekšstats par valodu ir specifisks. Daudzējādā ziņā viņu runu ietekmē valodas vides kvalitāte. Skolēni parasti sastopas ar nekvalitatīvu runu (vienkāršota sintakse, ḷoti daudz runas kḷūdu, pragmatisms). Mūsdienās vairāk nekā agrāk manāms, cik dažāds ir skolēnu runas prasmes līmenis, uzsākot skolas gaitas. Rezultātā rodas milzīga plaisa starp valodas zināšanām, skolēnu reālo valodas prasmi un to, ko gaidījis skolotājs. Tieši tāpēc pirmās (dzimtās) valodas stundās skolēni bieži uzdod jautājumu: „Kāpēc tā latviski/krieviski nedrīkst teikt/rakstīt? Es taču tā vienmēr runāju." Kārtējo reizi saskaramies ar to, par ko rakstijusi Svetlana Makejeva: „Skolēnu valodas kompetences apguves ierobežojumus visbiežāk rada plaisa starp apgūstamajām zināšanām par valodu un skolēna valodas pieredzi viņa individuālajā izaugsmē." (Макеева 2011: 8)

Otrs iemesls saistīts ar to, ka skolēnu gramatiskās spējas veidošanas nepietiekamais līmenis būtiski „bremzē” vinuu valodas kompetences attīstību. 
Mūsdienās ik pa laikam dzirdam dažādu priekšmetu (ne valodas) skolotāju un ierēdṇu, izglītības sfērā strādājošo izteikumus: „Kāpēc skolēns jāpiespiež mācīties konjugācijas, teikuma veidus, vārdšķiras? Tas viss ir lieks, skolēniem grūti. Galvenais - iemāciet sazināties!" Diemžēl vai par laimi, bez gramatikas zināšanām un gramatiskās (plašāk - valodas) spējas attīstības nav iespējams veidot sekmīgu komunikatīvu personību. Tas nav iepējams ne tikai pirmajā, bet arī pārējās valodās, kuras apgūst skolēns. Pennijs Urs pamatoti norāda - „nav divu domu par to, ka gramatikas likumu eksplicītās un implicītās zināšanas ir valodas apgūves pamats" (Ur 1992: 4).

Gramatiskās spējas plašākajā izpratnē ietver vairākas prasmes: veikt abstraktas darbības, lai izprastu gramatiskās vienības, gramatiskās kategorijas, izmantot gramatiskās vienības savā runā, lai veiktu komunikatīvos uzdevumus gan mutiski, gan rakstiski; izmantot gramatiskās zināšanas, lai pilnveidotu ortogrāfijas, interpunkcijas normu lietošanu, runas prasmju un valodas kultūras normu ievērošanu (Свечникова 2012: 7). Tātad skolēnam ne tikai jāzina valodas likumi, kuri regulē valodas lietojumu, viṇam jāspēj tos izmantot, valodnieciski domāt. Loǵiski, lai skolēns izprastu kādu valodas likumību, viņam ,jāiziet cauri” domāšanas posmiem. Ne velti to sauc par izpratni, kas no logikas viedokḷa ir domas par priekšmetu, kas izsaka tā galvenās pazīmes. Valodas (gramatikas) izpratne ir morfēmu, vārdu, teikumu u. tml. abstrahēšanas un būtisku pazīmju apkopojuma rezultāts (Рамзаева, Львов 1979: 239). Tātad jebkura jēdziena izpratnes pamatā ir būtiskās un mazāk svarīgās pazīmes, kas ietver individuālās un kopīgās kategorijas. Diemžēl skolās bieži nākas novērot situāciju, kad skolēni mehāniski iemācās lingvistiskos jēdzienus un likumus, neizprotot gramatisko jēdzienu būtību, neattīstot visas prasmes, kas veido izpratni. Visbiežāk, kā vērojams stundās, trūkst izpratnes, sintēzes un novērtējuma posmu.

Trešais iemesls - pretrunas starp skolēnu valodas zināšanām un to izmantošanu. Vairums skolēnu grūtības sagādā spēja definēt kādu valodas zīmi vai jēdzienu (nosaukt tā būtiskās pazīmes), izskaidrot tā lomu runā un nozīmību savas runas uzvedībai. Piemēram, sestklasnieki veiksmīgi var atrast vārdu savienojumu teikumā, bet nevar izskaidrot, kas ir vārdu savienojums. Skolēni zina, kāds burts konkrētajā vārdā, bet, līdzko pašam šis vārds jāuzraksta domrakstā, tiek pieḷautas kḷūdas. Var šḳist, ka prasme atrast ir svarīgāka nekā prasme raksturot valodas zīmes vai jēdziena būtību, bet tas tā nav. Prasme, kas veidojusies bez izpratnes (neapzināta prasme), nav ilglaicīga, noturīga, tā nesaglabājas cilvēka valodas pieredzē.

Tātad, veicot valodas materiāla analīzi, var secināt, ka Latvijas skolēnu valodas kompetences attīstības līmenis mūsdienās ir zems. Problēmas, ar kurām saskaras skolēni, veicot valodas uzdevumus, un pieḷautās kḷūdas pārbaudes darbos gadu no gada faktiski ir vienādas. Tas nozīmē, ka skolēnu gramatisko spēju (plašāk - viṇu valodas kompetences) pēctecīgajā 
attīstībā tiek ignorēti domāšanas posmi: valodas zīmju un jēdzienu būtības izpratne, to raksturīgo pazīmju analīze, to lomas tekstveidē un nozīmības skolēnu runas uzvedībā apzināšanās. Galvenais iemesls, mūsuprāt, ir tas, ka skolēniem dzimtās valodas apguves procesā neveidojas pilnvērtīgs valodas lingvistikais skatījums.

\section{SUMMARY}

The article is devoted to the analysis of the concept "language competence" and the problems in the development of linguistic competence of Form 6-9 students.

The introduction is focused on the content of the concept of "language competence", the necessity for the development of students' language skills in the process of their mother tongue (Latvian and Russian) studies.

Further, the authors analyse the problems in the development of students' language competence. The data presented in the article are based on the results of the analysis of diagnostic works of Form 6 and 9 students (2013-2016).

The research results substantiate the conclusion, that students

- have difficulties when they characterize a linguistic phenomenon (morpheme, word, subordinate word-group, sentence, text) based on its isolated grammatical indicators (signs);

- are not able to correctly predict a solution to the language problems (predictive skills);

- are not able to substantiate their position, analyze a language problem;

- formulate wrong or unnecessary arguments, analyze the language problem, and are not ready to defend the solution to the language problem.

The main reason why students face problems in the process of language learning is that they have difficulties in forming the linguistic view of language.

\section{LITERATŪRA}

Ur 1992

Ur, P. (1992) Grammar Practice Activities. A practical guide for teachers. New York: Cambridge University Press.

Van Ek 1986 Van Ek, J. A. (1986) Objectives for foreign language learning, 1. Scope. Strasbourg: Council of Europe Press.

Божович 1997 Божович, Е. Д. (1997) Развитие языковой компетенции школьников: проблемы и подходы. Вопросы психологии. 1. Москва: Изд-во „Школа-Пресс”, с. 33-44.

Божович 2013 Божович, Е. Д. (2013) Структура, динамика и механизмы развития языковой компетенции школьников. Психологическая наука и образование psyedu.ru., 5. Piekluve: http://psyedu.ru/ journal/2013/5/ Bozhovich.phtml [Skatìts: 30.05.2017.]

Быстрова, Львова Быстрова, Е. А., Львов, С. И. (2004) Обучение русскому языку 2004 в школе: учебное пособие для студентов педагогических вузов. Москва: Дрофа. 
Быстрова 2004 Быстрова, Е. А. (2004) Цели обучения русскому языку, или Какую компетенцию мы формируем на уроках. Обучение русскому языку в школе: учебное пособие для студентов педагогических вузов. Москва: Дрофа.

Голованова 2004 Голованова, И. Ю. (2004) Проблема анализа речевых ошибок в контексте онтогенеза языковой компетенции. Автореф. дисс. канд.филол. наук. Челябинск: ЧГУ. Piekḷuve: http://cheloveknauka. com/ problema-analiza-rechevyh-oshibok-v-kontekste-ontogenezayazykovoy-kompetentsii [Skatîts: 31.05.2017.]

Макеева 2011 Макеева, С. Г. (2011) Языковая компетенция как результат языкового развития. Ярославский педагогический вестник. Ярославль: ЯГПУ им. К. Ушинского, 4 (II) (Психологопедагогические науки), с. 7-9.

Рамзаева, Львов Рамзаева, Т. Г., Львов, М. Р. (1979) Методика обучения русскому 1979 языку в начальных классах: учебное пособие для студентов институтов по специальности № 2121 „Педагогика и методика нач. обучения". Москва: Просвещение.

Романова, Романова, Н. Н., Филиппов, А. В. (2009) Словарь. Культура Филиппов 2009 речевого Филиппов 2009 общения: этика, прагматика, психология. Москва: Флинта.

Свечникова 2012 Свечникова, О. Н. (2012) Формирование грамматической способности учащихся 7-го класса общеобразовательной школы на основе системно-функционального подхода при изучении причастия. Автореф. дисс. канд. пед. наук. Орел.

Химик 2004 Химик, В. В. (2004) Большой словарь русской разговорной экспрессивной речи. СПб.: НОРИНТ.

Хруцкая 2013 Хруцкая, Н. В. (2013) Размышления о понятиях „лингвистическая компетенция” и „лингвистическая компетентность”. Науковий часопис НПУ імені М. П. Драгоманова. Серія 9, Сучасні тенденції розвитку мов. Випуск 10: збірник наукових праць. Ред. В. І. Гончарова. Киев: Видавництво НПУ імені М. П. Драгоманова, c. 271-276. 